\title{
Environment as a Complex System: the Malaria Decrease in the Legal Amazonia (LA) Case
}

\author{
O meio ambiente como um sistema complexo: o caso da diminuição da malária \\ na Amazônia Legal (LA)
}

\section{L'environnement en tant que système complexe: la diminution du paludisme dans l'Amazonie Légale (LA)}

\author{
El medio ambiente como sistema complejo: el caso de la disminución de la \\ malaria en la Amazonia Legal (LA)
}

\author{
Arlindo Kamimura ${ }^{1}$ \\ Geraldo Burani ${ }^{1}$ \\ Ildo Sauer ${ }^{1}$
}

Recebido em 31/08/2017; revisado e aprovado em 01/11/2017; aceito em 14/11/2017

DOI: http://dx.doi.org/10.20435/inter.v19i3.1701

\begin{abstract}
In Brazil, malaria is an endemic disease present mainly in the Legal Amazon (LA), which accounts for more than 99\% of the country's cases. In 2000 the number of new cases of malaria in LA was 613.3 thousand, decreasing to 265.4 thousand cases in 2011 , thus dropping by $56.7 \%$. The malaria system behavior depends on many interrelated variables and environmental factors, constituting itself in a complex, non-linear dynamical living system, whose resulting dynamics have as main characteristics the unpredictability and the extreme sensitivity to the initial conditions. This paper is an investigation of a possible additional cause for the huge decrease in cases of malaria in the states of LA, in addition to the already recognized governmental effort to malaria disease control. The hypothesis adopted is that all domestic animals (exception fowls) compete with the man in the position of hosts feeding of the mosquito Anopheles, vector-borne of the disease.
\end{abstract}

Keywords: environment; epidemiology; malaria.

Resumo: No Brasil, a malária é uma doença endêmica presente principalmente na Amazônia Legal (LA), que representa mais de $99 \%$ dos casos do país. Em 2000, o número de novos casos de malária em LA foi de 613,3 mil, diminuindo para 265,4 mil casos em 2011, queda de 56,7\%. O sistema de propagação da malária depende de muitas variáveis inter-relacionadas e fatores ambientais, constituindo-se em um sistema complexo e não-linear, cuja dinâmica resultante tem como principais características a imprevisibilidade e a extrema sensibilidade às condições iniciais. Este artigo é uma investigação de uma possível causa adicional para a enorme diminuição nos casos de malária nos estados da LA, além do já reconhecido esforço governamental para o controle da doença. A hipótese adotada é que todos os animais domésticos (exceto as galinhas) competem com o homem na posição de hospedeiro do mosquito Anopheles, vetor transmissor da malária.

Palavras-chave: meio-ambiente; epidemiologia; malária.

Résumé: Au Brésil, le paludisme est une maladie endémique présente principalement dans l’Amazonie Légale (LA), ce qui représente plus de $99 \%$ des cas du pays. En 2000, le nombre de nouveaux cas de paludisme à LA était de 613,3 mille, en baisse de 265,4 mille cas en 2011 , en chute donc de 56,7\%. Le système de propagation du paludisme dépend de nombreuses variables interreliées et facteurs environnementaux, constituant un système complexe et non linéaire, dont la dynamique résultante a comme caractéristiques principales l'imprévisibilité et l'extrême sensibilité aux conditions initiales. Cet article est une enquête sur une possible cause supplémentaire pour la diminution énorme des cas de paludisme dans les états de LA, en plus de l'effort gouvernemental déjà reconnu pour contrôler la maladie. L'hypothèse adoptée est que tous les animaux domestiques (à l'exception des poulets) sont en concurrence avec l'homme, dans la position hôte du moustique Anopheles, vecteur émetteur du paludisme.

Mots clés: environnement; épidémiologie; paludisme.

Resumen: En Brasil, la malaria es una enfermedad endémica presente principalmente en la Amazonia Legal (LA), que representa más del 99\% de los casos del país. En 2000, el número de nuevos casos de malaria en LA fue de 613,3 mil, disminuyendo a 265.400 casos en 2011, caída del 56,7\%. El sistema de propagación

\footnotetext{
${ }^{1}$ Universidade de São Paulo (USP), Instituto de Energia e Meio Ambiente (IEE), São Paulo, Brasil.
} 
de la malaria depende de muchas variables interrelacionadas y factores ambientales, constituyéndose en un sistema complejo y no lineal, cuya dinámica resultante tiene como principales características la imprevisibilidad y la extrema sensibilidad a las condiciones iniciales. Este artículo es una investigación de una posible causa adicional para la enorme disminución en los casos de malaria en los estados de la LA, además del ya reconocido esfuerzo gubernamental para el control de la enfermedad. La hipótesis adoptada es que todos los animales domésticos (excepto las gallinas) compiten con el hombre, en la posición de huésped del mosquito Anopheles, vector transmisor de la malaria.

Palabras clave: medio ambiente; epidemiología; malária.

\section{INTRODUCTION}

Malaria is still one of the most important public health problems affecting the world. According to World Health Organization (WHO, 2017), 212 million new cases worldwide appeared in 2015, with 429 thousands deaths, of which, approximately $70 \%$, reaching primarily children under five.

In Brazil, malaria is an endemic disease present mainly in the Legal Amazon (LA), which accounts for more than 99\% of the country's cases. The Legal Amazon is constituted by nine states of the North and Midwest of Brazil, namely: Amazonas (AM), Pará (PA), Acre (AC), Rondonia (RO), Amapá (AP), Roraima (RR), Tocantins (TO), Mato Grosso (MT) and Maranhão (MA), totaling 5.217 million square kilometers, or $61 \%$ of the Brazilian territory. In LA there live about 23 million people, that is $12 \%$ of the total Brazilian population (IBGE, 2010). In 2000 the number of new cases of malaria in LA was 613.3 thousand, decreasing to 265.4 thousand cases in 2011, thus dropping by 56.7\%. This fall continues, so that in 2014 were registered 144 thousand cases (BRASIL, 2013; FERREIRA; CASTRO, 2016) and in 2016, 129.2 thousands cases (BRASIL, 2017). In Brazil, three species of malaria parasites are transmitted: Plasmodium falciparum, Plasmodium malariae and Plasmodium vivax, the latter being responsible for $78.7 \%$ of the cases reported in LA between 2000 and 2011 (BRASIL, 2013). The vector of propagation of the disease is the female of the genus Anopheles mosquito, which together with human host and some few nonhuman primates complete the life cycle of Plasmodium parasite (CAMUS; TERENCE; 1985, p. 553).

The malaria system behavior depends on many interrelated variables and environmental factors, constituting itself in a complex, non-linear dynamical living system, whose resulting dynamics have as main characteristics the unpredictability and the extreme sensitivity to the initial conditions (ABRAHAM; SHAW, 2000). As an example of a complex living system, we have the behavior of economics, whose results are only possible to be analyzed in an "ex post" way (KAMIMURA; BURANI; FRANÇA, 2011). The malaria system presents also the "spontaneous" or natural disappearance of the disease as a possible solution. By spontaneous we mean that the final result was unintentionally obtained by man. The natural disappearance of malaria from certain areas has been observed in several countries of the world, as in the Netherlands, for example, recounted by Swellengrebel (1950) and MacDonald et al. (1956). The causes of these natural eradications are difficult to trace, but small changes in the environment can in some cases lead to the complete disappearance of malaria (BRUMPT, 1944). The main known causes of an epidemic increase of malaria disease are: a suitable temperature for the development of the Plasmodium in the Anopheles mosquito, the density of mosquitos in relation to man, the fraction of infected mosquitos, the frequency with which the mosquitos bites man, the longevity of the vector, the human recovery time of the disease (DOBSON; FOUFOPOULOS, 2001; WAITE, 
1910). As an example of the complexity of the malaria dynamics, a paper from Lacroix (LACROIX et al., 2005) shows that malaria infection increases attractiveness of humans to mosquitoes, revealing the exponential growth feature due to variable self-influence in the infection process.

The environmental and social factors associated with these epidemic causes are the following: deforestation, climate, temperature, hydrology, human migratory movements, population density and human activities that intensify man contact with mosquitoes such as: open digging mines, agriculture, wood farming, fish farming, inappropriate disposal of industrial and domestic waste, spontaneous human settlements and others (SAWYER, 1986; BARATA, 1995; PAHO, 2003; BRASIL, 2001).

Some mathematical models derived from biomathematics are unanimous in showing two basic results: a) for a given number of mosquitoes per unit of population, or equivalently, the number of mosquito bites per unit of time, per person, the number of cases of malaria gradually increases or falls to a fixed value in which it remains stationary and b) when the number of Anopheles is less than a certain value (or bites in human/unit time), there is no condition of stability and cases of disease fall gradually to finally disappear altogether (DOBSON; FOUFOPOULOS, 2001 ; WAITE, 1910; ROSS, 1916; DIEKMANN; HEESTERBEEK; BRITTON, 2013 ; SHONKWILER; ANEKE, 1999 ; ARON, 1988; SMITH, 2007).

The accepted explanation for the reduction of malaria in LA is due to government programs only. The objective of this work is to investigate other than official recognized explanatory variables, which there is a reduction of bites in humans, leading to the possibility of "spontaneous" decrease of malaria cases in the Legal Amazonia.

\section{DEFORESTING AND MALARIA IN THE LEGAL AMAZONIA (LA)}

Deforestation in the Legal Amazon is the main suspect of malaria growth in this region. A paper of Sarah Olson, from Wisconsin University (OLSON et al., 2010), determine whether deforestation is associated with malaria incidence in the county of Mâncio Lima, in the State of Acre (AC), belonging to the "Arc of Deforestation", defined ahead, as a part of LA. According to Olson (OLSON, 2010n): "It appears that deforestation is one of the initial ecological factors that can trigger a malaria epidemic". In this study, the author shows a correlation between tree felling, mosquito's proliferation and a higher incidence of human infections. "Human-altered landscapes provide a milieu of suitable larval habitats for Anopheles darling mosquitoes, including road ditches, dams, mining pits, culverts, vehicle ruts, and areas of poor clearing" (OLSON, 2010). Sawyer (SAWYER, 1988) showed that deforestation causes malaria while it is ongoing and reduces it afterwards. Table 1 shows the number of "Green Warnings" in the "Arc of Deforestation" (ARAUJO, 2007). 
Figure 1 - Number of infected people (thousands) by malaria in the LA between 2000 and 2011

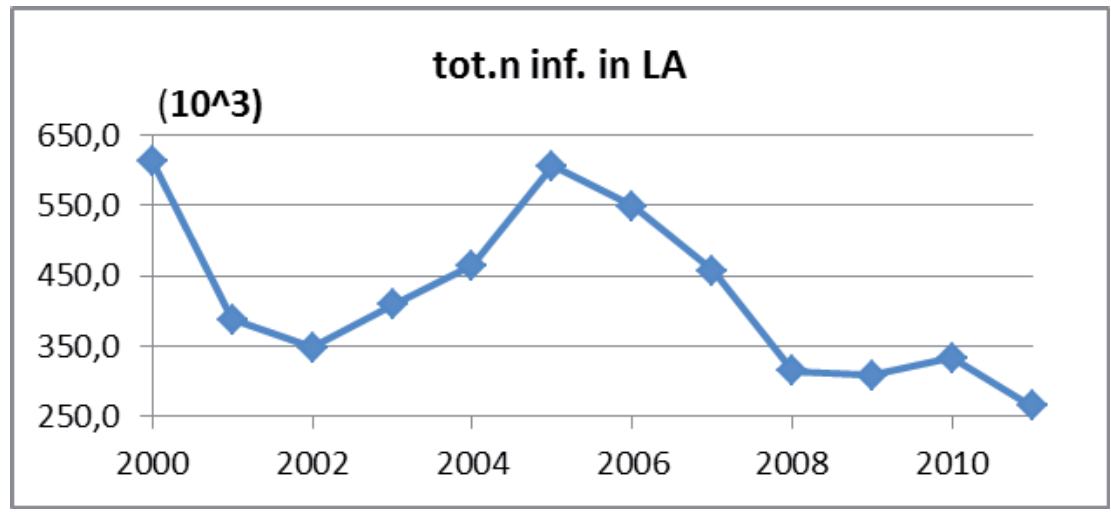

Source: Brasil (2013).

Table 1 - Number of "Green Warnings", indicating deforestation activity in the whole Legal Amazon (A) and in the "Arc of Deforestation" (B)

\begin{tabular}{|c|c|c|c|}
\hline year & $(\mathbf{A})$ & $(\mathbf{B})$ & (B/A) \\
\hline 2002 & 2947 & 2269 & $77 \%$ \\
\hline 2003 & 5025 & 4281 & $85 \%$ \\
\hline 2004 & 5061 & 4185 & $83 \%$ \\
\hline 2005 & 1492 & 1209 & $81 \%$ \\
\hline 2006 & 1505 & 1108 & $74 \%$ \\
\hline
\end{tabular}

Source: Araujo (2007).

Table 2 - Number of counties per deforestation percentage class in LA

\begin{tabular}{|c|c|c|c|c|c|c|c|}
\hline Deforesting \% & $\mathbf{2 0 0 0}$ & $\mathbf{2 0 0 1}$ & $\mathbf{2 0 0 2}$ & $\mathbf{2 0 0 3}$ & $\mathbf{2 0 0 4}$ & $\mathbf{2 0 0 5}$ & $\mathbf{2 0 0 6}$ \\
$<20$ & 446 & 391 & 387 & 371 & 367 & 360 & 354 \\
$20-50$ & 115 & 129 & 125 & 130 & 127 & 127 & 127 \\
$50-80$ & 117 & 139 & 140 & 144 & 145 & 146 & 150 \\
$>80$ & 103 & 122 & 129 & 136 & 142 & 148 & 150 \\
\hline
\end{tabular}

Source: Rivero et al. (2009) and INPE (2008).

As mentioned before, the key variable in the malaria spreading process is the number of bites that each mosquito gives in humans per unit of time. According to Vittor et al. (2006) the mean biting rate in areas with $>80 \%$ deforestation was 8.33 compared with 0.03 per night for sites with $<30 \%$ deforestation. This agree with the re-emergence of malaria between 2002 and 2005, shown in Figure 1 and the level of deforestation shown in Table 1 and Table 2, for the same period in LA: the number of counties in LA with less than $20 \%$ deforestation decrease $7.9 \%$ in (2002-2005) and the number of counties with more than $80 \%$ deforestation grows $14.7 \%$. The number of counties with $20 \%-80 \%$ deforestation also grows in this period (RIVERO et al., 2009; INPE, 2008). This deforestation occurred mainly in the well-known "Arc of Deforestation", with a spatial configuration that includes the west and northwest of Maranhão (MA), the east, south and part of the west of Pará (PA), the west and the north of Tocantins (TO), the east, center-west and north of Mato Grosso (MT), the entire state of Rondonia (RO) and Acre (AC) and southern Amazonas (AM). This configuration comprises 248 counties (MIDIAEAMAZONIA, 2014). 


\section{GOVERNMENT ACTION AGAINST MALARIA}

The first campaign against malaria in Brazil took place in 1905, during the construction of the port of Santos, in the state of São Paulo by the sanitary physician Carlos Chagas. The following papers (BARATA, 1995; SILVA; PAIVA, 2015; BRASIL, 2017; LOIOLA; SILVA; TAUIL, 2002) provide a historical assessment of malaria programs, which were implemented over the years:

1938-1939: a massive anti-malaria program with partial support from the Rockefeller Foundation. 1947: Large-scale DDT fumigation program.

1965: adoption of the CEM - Global Malaria Eradication Program defined by WHO.

1989: launch of PCMAM - Amazon Basin Malaria Control Programme.

2000: launch of PIACM - Intensification Plan of Malaria Control Activities.

2003: launch of NMPCP - National Malaria Prevention and Control Programme.

2015: launch of the Malaria Elimination Plan.

2017: launch of the Prevention and Incentive Campaign to Treat Malaria.

The paper on malaria control in Brazil between (1965-2001) years, Loiola (LOIOLA; SILVA; TAUIL, 2002) makes an assessment of the several programs developed in this period, in which the application of the resources would be carried out by the counties participating in the programs. He recognizes the importance of such programs in the success of malaria eradication, but makes some criticisms as to how they are implemented and their effectiveness. Following his words: "[...] the expected impact with the injection of new resources and the involvement of counties was sadly frustrating [...]" and "[...] very few counties actually fulfilled what was proposed in the work plans. Many counties have used resources differently from the one planned". Even so, in 1999, 631 thousand cases were registered in LA, falling to 384 thousand in 2001, a drop of 39\%, an index never reached until then since 1960. According to his words to explain the success of the malaria battle: "[...] Never in the history of malaria control in Amazonia since 1960 has there been such a high reduction in the transmission of malaria. To explain such a reduction, the only recognized independent variable was the implementation of PIACM from 2000".

More recently, Brazil recorded a 76.8\% decrease in malaria incidence between 2000 and 2014 (FERREIRA; CASTRO, 2016). There is no doubt that this extraordinary achievement is the result of the continuous effort made by the government during those years. However, in this paper, we suggest a possible variable to explain the decrease of Anopheles bites in humans, looking for another factor that could help to understand such a significant decaying in LA malaria disease.

\section{THE HUMAN BEING VERSUS CATTLE AS A FEEDING HOST OF THE MALARIA VECTOR HYPOTHESIS}

Spontaneous or unintentionally regression of malaria (RAMSDALE, 2010) was first described by Roubaud (1920), in which he describes how cattle provided protection to the population against malaria in parts of Normandy. He, as several authors in Ramsdale (2010) concluded that the female of the Anopheles mosquito exhibits a decided preference for certain species as blood hosts. Roubaud (1920) asserts that all common domestic animals, except chicken, are the preferred blood hosts and that man is chosen only in the absence of such animals. The disappearance of malaria from Denmark between 1830 and 1900 may be related to Anopheles host preference for animals (ROUBAUD, 1920; RAMSDALE, 2010; BULL; ROOT, 1923), (BAILLY-CHOUMARA, 1973). 
The almost complete eradication of malaria from the Vendée region and outskirts of Paris, France is attributed to the fact pointed by Bull (BULL; ROOT, 1923): "the malaria-bearing mosquitoes of these sections have, within recent years, developed a decided preference for the domestic animals as blood hosts". Toty et al. (2010) claim that: "...Immuno-assay analysis [42] of 20 blood meals in resting Anopheles labranchiae females collected in a cowshed at Saleccia in July 2008 showed that they had preferentially fed on bovines ( $n=19)$, but one individual had bitten a human. These results are consistent with those of Bailly-Choumara [43] in Morocco in May 1968, who observed that this species could feed on a variety of mammals, including humans (5.1\%), but that bovines were the preferred host ( $82.4 \%, n=1126$ blood meals analysed)...".

The almost eradication of malaria in Italy is also due to the presence of cattle. According to Majori (2012): "Missiroli and Hackett, in collaboration with the German entomologist Erich Martini, finally solved the enigma of the "anophelism without malaria" in 1933. They discovered that in Italian areas with low malaria endemicity, the dominant anopheline mosquitoes were those biting exclusively or preferably the cattle, and consequently not participating in the transmission of the disease. The observation was confirmed by comparing the intestinal contents of engorged mosquitoes, collected in animal's shelters and in human dwellings, using immune sera according to the method developed in 1922 by American researchers in Louisiana."

Barata's paper (1995) on the epidemiological panorama of malaria in Brazil in the last ten years says that pasture areas have a low incidence of the disease in humans.

In the Legal Amazon LA, where malaria is considered an endemic disease, the main cause of epidemic outbreaks is credited to deforestation, as mentioned previously, through the mosquitoes Anopheles darlingi as a prevailing malaria vector disease. The feeding preferences habit of such mosquitoes was first studied in Belém, Pará by Deane et al. (1949) and afterwards by Oliveira et al. (1989) and Ferreira et al. (1992). They concluded that the A. darlingi habits vary a lot in relation to their preferred feeding hosts but that they are essentially anthropophilic, but also exhibits zoophilic feeding habits.

Deforestation has in LA occurred primarily as an economic activity, with extraction goals (gold, wood, noble woods) and then the deforested areas transformed mainly into pasture for cattle ranching. Cattle ranching are the activity most strongly correlated with deforestation for the counties of LA, with a correlation coefficient of 0.7345 between the number of cattle and deforestation (RIVERO et al., 2009).

The hypothesis adopted in this work to decrease the mosquitos' bites in human is the substitution of man as an Anopheles feed host by another animal, mainly cattle. It is obvious that this hypothesis will only be valid in cases where there is a sufficiently close coexistence between the communities and the cattle herd or others animals.

The annual growth rate of the cattle herd in the LA has been enormous, much higher than in Brazil between 1991 and 2005. While in Brazil the herd grew at an annual rate of 1\%, this rate was 7\% in LA, between 2000 and 2005 (27; 39) (Figure 2). The growth of the cattle herd between 2000 and 2012 in the LA was 68\%, from 47.5 million in 2000 to 80 million in 2012 (figure 3). 
Figure $\mathbf{2}$-Annual growth rates of cattle herds in Brazil and in the LA

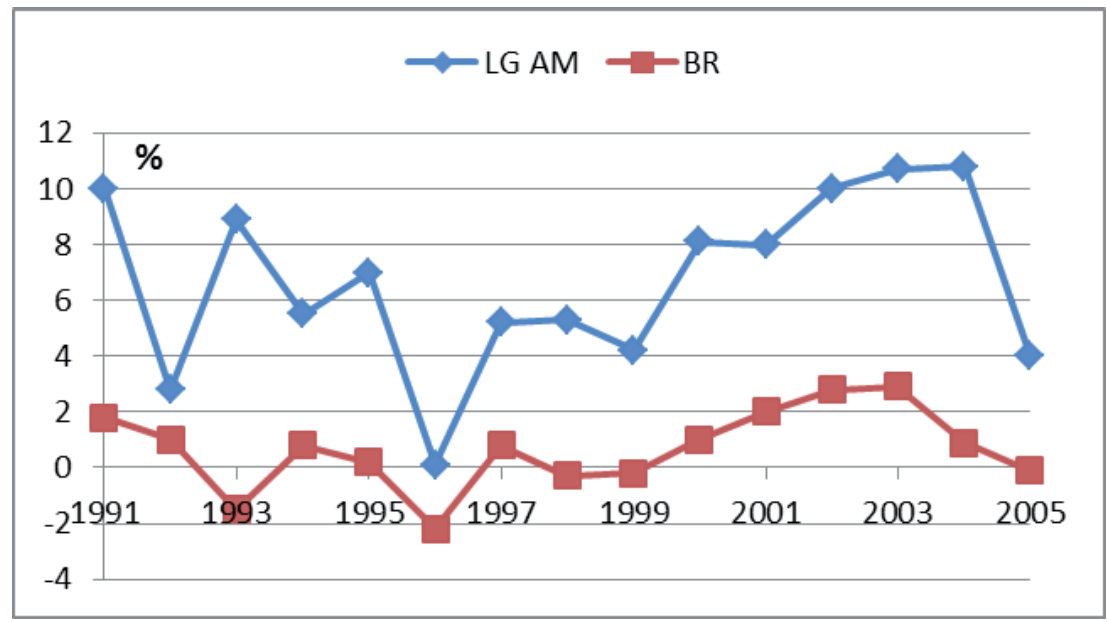

Source: Rivero et al. (2009) and IBGE (2017).

Figure 3 - Total cattle herd in the Legal Amazon (million)

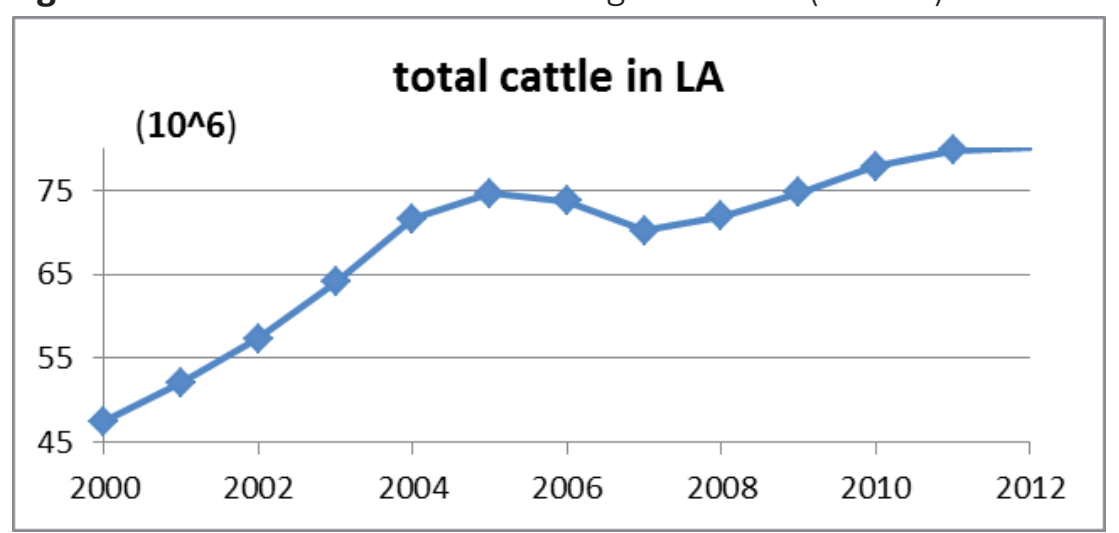

Source: IBGE (2017).

The study consists in establishing correlations between the bovine herd and the number of malaria infections in each component state of LA, in the years 2000-2011. The corresponding data are available in (SVS, 2013) and (IBGE, 2017).

\section{RESULTS: CORRELATION BETWEEN THE NUMBERS OF PEOPLE INFECTED WITH MALARIA AND THE NUMBER OF CATTLE DISAGGREGATED BY LA STATES}

\subsection{Maranhão State (MA)}

Table 3 - (MA) Population, malaria number of infection $\left(10^{\wedge} 3\right)$, number of cattle herd $\left(10^{\wedge} 6\right)$ and the correlation coefficient Infected people $\mathrm{x} n$. cattle

\begin{tabular}{|c|c|c|c|c|c|c|c|c|c|c|c|c|}
\hline (MA) & 2000 & 2001 & 2002 & 2003 & 2004 & 2005 & 2006 & 2007 & 2008 & 2009 & 2010 & 2011 \\
\hline pop.(10^3) & 5652 & 5731 & 5803 & 5874 & 6022 & 6103 & 6185 & 6280 & 6377 & 6475 & 6575 & 6676 \\
\hline Infect. $\left(10^{\wedge} 3\right)$ & 78,8 & 39,5 & 16 & 11,4 & 14,5 & 11,2 & 9,5 & 6,6 & 4,8 & 5,7 & 3,9 & 3,5 \\
\hline catt. $\left(10^{\wedge} 6\right)$ & 4,1 & 4,3 & 4,78 & 5,51 & 5,93 & 6,45 & 6,61 & 6,61 & 6,82 & 6,89 & 6,98 & 7,26 \\
\hline \multicolumn{13}{|c|}{ Correlation $2000 / 2011=-\mathbf{0 , 8 2}$} \\
\hline
\end{tabular}

Source: Brasil (2013) and IBGE (2017). 
Figure $4-(M A)$ Correlation between infection $\left(10^{\wedge} 3\right)$ and cattle numbers $\left(10^{\wedge} 6\right)$

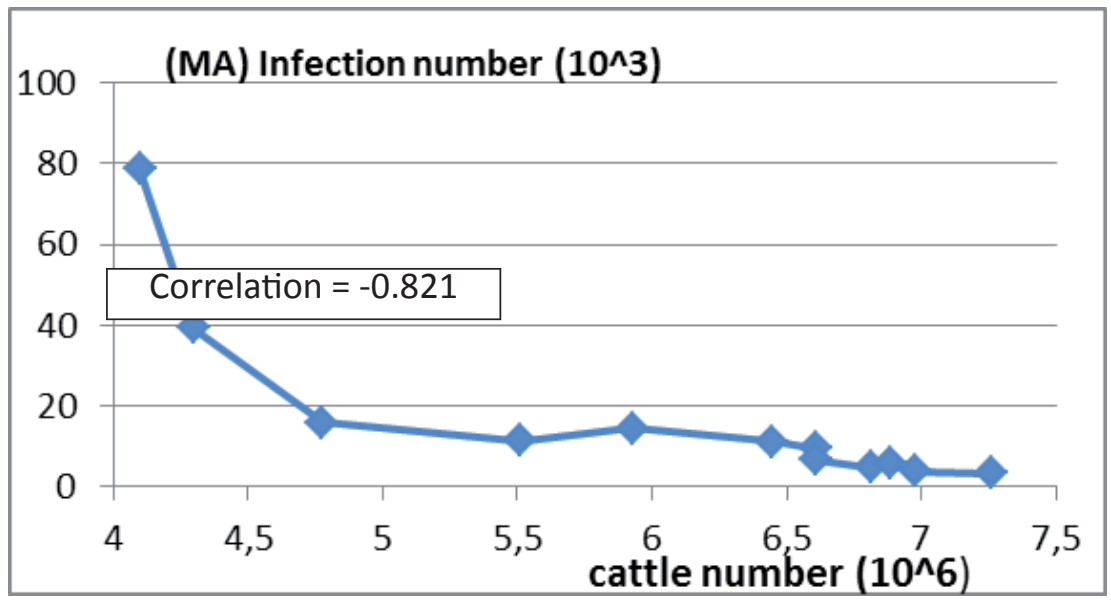

Source: Brasil (2013) and IBGE (2017).

In the $2000-2011$ years:

- Correlation malaria infection $x$ cattle herd 2000/2011=-0.82

- Average cattle number/population $=0.97$

- Average infection/year (thousands) = 17.1

- Fall of infections cases $(\%)=95.6$

- Growth of cattle herd $(\%)=77.2$

\subsection{Mato Grosso State (MT)}

Table 4 - (MT) Population, malaria number of infection (10^3), number of cattle herd (10^6) and the correlation coefficient Infected people $\times \mathrm{n}$. cattle

\begin{tabular}{|c|c|c|c|c|c|c|c|c|c|c|c|c|}
\hline (MT) & 2000 & 2001 & 2002 & 2003 & 2004 & 2005 & 2006 & 2007 & 2008 & 2009 & 2010 & 2011 \\
\hline pop.(10^3) & 2504 & 2561 & 2605 & 2651 & 2749 & 2803 & 2857 & 2900 & 2945 & 2989 & 3035 & 3081 \\
\hline Infect.(10^3) & 11,8 & 6,8 & 7,1 & 5 & 6,5 & 8,5 & 6,7 & 6,8 & 4,1 & 3,3 & 2,4 & 1,6 \\
\hline catt. $\left(10^{\wedge} 6\right)$ & 18,9 & 20,5 & 22,18 & 24,61 & 25,92 & 26,65 & 26,06 & 25,68 & 26,02 & 27,36 & 28,76 & 29,27 \\
\hline \multicolumn{13}{|c|}{ Correlation $2000 / 2011=\quad \mathbf{0 , 7 8}$} \\
\hline
\end{tabular}

Source: Brasil (2013) and IBGE (2017).

In the $2000-2011$ years:

- Correlation malaria infection $x$ cattle herd $2000 / 2011=-0.78$

- Average cattle number/population $=8.94$

- Average infection/year (thousands) $=5.9$

- Fall of infections cases (\%) $=86.4$

- Growth of cattle herd $(\%)=54.8$ 


\subsection{Pará State (PA)}

Table 5 - (PA) Population, malaria number of infection (10^3), number of cattle herd $\left(10^{\wedge} 6\right)$ and the correlation coefficient Infected people $x \mathrm{n}$. cattle

\begin{tabular}{|c|c|c|c|c|c|c|c|c|c|c|c|c|}
\hline (PA) & 2000 & 2001 & 2002 & 2003 & 2004 & 2005 & 2006 & 2007 & 2008 & 2009 & 2010 & 2011 \\
\hline pop.(10^3) & 6192 & 6342 & 6454 & 6575 & 6850 & 6971 & 7110 & 7225 & 7342 & 7460 & 7581 & 7704 \\
\hline Infect.(10^3) & 278,2 & 186,4 & 149,1 & 115,5 & 109,8 & 123,4 & 101,8 & 76,2 & 69,2 & 99,6 & 135,2 & 114,8 \\
\hline catt. $\left(10^{\wedge} 6\right)$ & 10,3 & 11 & 12,19 & 13,38 & 17,43 & 18,06 & 17,50 & 15,35 & 16,24 & 16,87 & 17,63 & 18,26 \\
\hline \multicolumn{13}{|c|}{ Correlation 2000/2011 $=-0,72$} \\
\hline
\end{tabular}

Source: BRASIL (2013 and IBGE (2017).

In the $2000-2011$ years:

- Correlation malaria infection $x$ cattle herd 2000/2011=-0.72

- Average cattle number/population $=2.18$

- Average infection/year (thousands) $=129.9$

- Fall of infections cases $(\%)=58.8$

- Growth of cattle herd $(\%)=77.3$

\subsection{Tocantins State (TO)}

Table 6 - (TO) Population, malaria number of infection (10^3), number of cattle herd $\left(10^{\wedge} 6\right)$ and the correlation coefficient Infected people $\times \mathrm{n}$. cattle

\begin{tabular}{|c|c|c|c|c|c|c|c|c|c|c|c|c|}
\hline (TO) & 2000 & 2001 & 2002 & 2003 & 2004 & 2005 & 2006 & 2007 & 2008 & 2009 & 2010 & 2011 \\
\hline pop.(10^3) & 1157 & 1185 & 1207 & 1230 & 1263 & 1306 & 1332 & 1345 & 1358 & 1371 & 1384 & 1397 \\
\hline Infect.(10^3) & 1,6 & 1,2 & 1,1 & 1,2 & 0,9 & 0,7 & 0,4 & 0,3 & 0,2 & 0,1 & 0,1 & 0,1 \\
\hline catt.(10^6) & 6,1 & 6,5 & 6,98 & 7,66 & 7,93 & 7,96 & 7,76 & 7,40 & 7,39 & 7,61 & 7,99 & 8,03 \\
\hline \multicolumn{13}{|c|}{ Correlation 2000/2011= $-\mathbf{0 , 6 9}$} \\
\hline
\end{tabular}

Source: BRASIL (2013) and IBGE (2017).

In the $2000-2011$ years:

- Correlation malaria infection x cattle herd 2000/2011=-0.69

- Average cattle number/population $=5.75$

- Average infection/year (thousands) $=0.7$

- Fall of infections cases $(\%)=93.8$

- Growth of cattle herd $(\%)=31.6$

\subsection{Amapá State (AP)}

Table 7 - (AP) Population, malaria number of infection (10^3), number of cattle herd $\left(10^{\wedge} 6\right)$ and the correlation coefficient Infected people $\times \mathrm{n}$. cattle

\begin{tabular}{|c|c|c|c|c|c|c|c|c|c|c|c|c|}
\hline (AP) & 2000 & 2001 & 2002 & 2003 & 2004 & 2005 & 2006 & 2007 & 2008 & 2009 & 2010 & 2011 \\
\hline pop.(10^3) & 477 & 499 & 520 & 535 & 537 & 595 & 616 & 629 & 642 & 656 & 670 & 684 \\
\hline Infect.(10^3) & 35,3 & 24,5 & 16,3 & 16,7 & 20,7 & 28,1 & 29,3 & 22 & 15,1 & 15,5 & 15,4 & 19 \\
\hline catt. $\left(10^{\wedge} 6\right)$ & 0,08 & 0,08 & 0,08 & 0,08 & 0,08 & 0,10 & 0,11 & 0,10 & 0,10 & 0,11 & 0,12 & 0,13 \\
\hline \multicolumn{13}{|c|}{ Correlation $2000 / 2011=-\mathbf{0 , 2 3 4}$} \\
\hline
\end{tabular}

Source: BRASIL (2013) and IBGE (2017). 
In the $2000-2011$ years:

- Correlation malaria infection x cattle herd 2000/2011=-0.234

- Average cattle number/population = 0.16

- Average infection/year (thousands) $=21.5$

- Fall of infections cases $(\%)=46.2$

- Growth of cattle herd $(\%)=60.0$

\subsection{Acre State (AC)}

Table 8 - (AC) Population, malaria number of infection (10^3), number of cattle herd $\left(10^{\wedge} 6\right)$ and the correlation coefficient Infected people $\times \mathrm{n}$. cattle

\begin{tabular}{|c|c|c|c|c|c|c|c|c|c|c|c|c|}
\hline (AC) & 2000 & 2001 & 2002 & 2003 & 2004 & 2005 & 2006 & 2007 & 2008 & 2009 & 2010 & 2011 \\
\hline pop.(10^3) & 558 & 574 & 587 & 601 & 630 & 670 & 687 & 698 & 710 & 722 & 734 & 746 \\
\hline Infect.(10^3) & 21,6 & 7,8 & 9,2 & 12,3 & 31,7 & 57,2 & 93,9 & 51,3 & 27,7 & 27,6 & 36,9 & 22,6 \\
\hline catt.(10^6) & 1,03 & 1,4 & 1,82 & 1,88 & 2,06 & 2,31 & 2,45 & 2,32 & 2,43 & 2,51 & 2,58 & 2,55 \\
\hline \multicolumn{13}{|c|}{$\begin{array}{l}\text { Correlation 2000/2011 }=\mathbf{0 , 4 9} \\
\text { Correlation 2005/2011 }= \\
-\mathbf{0 , 3 9 5}\end{array}$} \\
\hline
\end{tabular}

Source: BRASIL (2013) and IBGE (2017).

In the $2000-2011$ years:

- Correlation malaria infection $x$ cattle herd 2000/2011=0.49

- Correlation malaria infection $x$ cattle herd 2005/2011=-0.395

- Average cattle number/population = 3.16

- Average infection/year (thousands) $=33.3$

- Growth of infections cases $(\%)=4.8$

- Growth of cattle herd $(\%)=147.6$

In the $2006-2011$ : Fall of infections cases $=75.9 \%$

\subsection{Amazon State (AM)}

Table 9 - (AM) Population, malaria number of infection $\left(10^{\wedge} 3\right)$, number of cattle herd $\left(10^{\wedge} 6\right)$ and the correlation coefficient Infected people $\times \mathrm{n}$. cattle

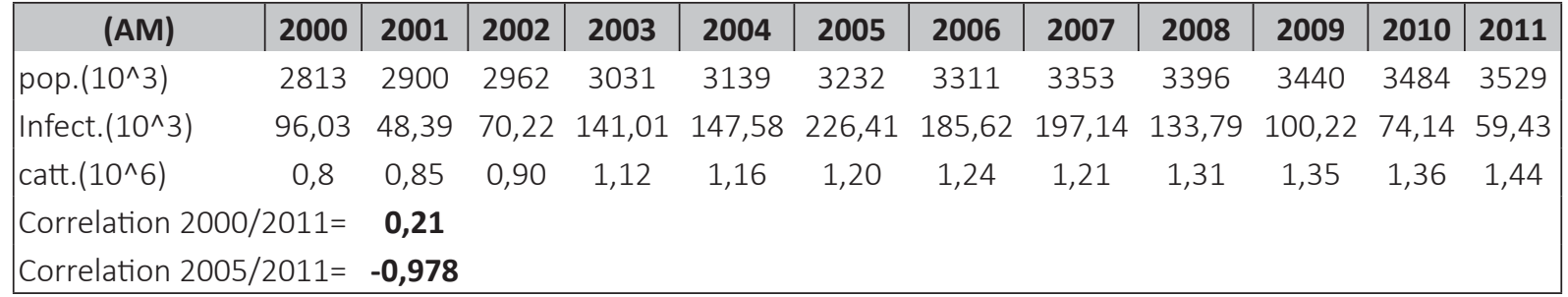

Source: BRASIL (2013) and IBGE (2017).

In the 2000-2011 years:

- Correlation malaria infection $x$ cattle herd 2000/2011=0.21

- Correlation malaria infection x cattle herd 2005/2011=-0.978

- Average cattle number/population = 0.36 
- Average infection/year (thousands) $=123.3$

- Fall of infections cases $(\%)=38.1$

- Growth of cattle herd $(\%)=80.0$

\subsection{Roraima State (RR)}

Table 10 - (RR) Population, malaria number of infection (10^3), number of cattle herd $\left(10^{\wedge} 6\right)$ and the correlation coefficient Infected people $\mathrm{x} n$. cattle

\begin{tabular}{|c|c|c|c|c|c|c|c|c|c|c|c|c|}
\hline (RR) & 2000 & 2001 & 2002 & 2003 & 2004 & 2005 & 2006 & 2007 & 2008 & 2009 & 2010 & 2011 \\
\hline pop.(10^3) & 324 & 337 & 347 & 357 & 382 & 391 & 403 & 414 & 426 & 438 & 451 & 464 \\
\hline Infect.(10^3) & 35,9 & 16 & 8 & 11,8 & 26,2 & 32 & 20,6 & 15,2 & 10,2 & 15 & 21,8 & 14 \\
\hline catt.(10^6) & 0,5 & 0,45 & 0,42 & 0,42 & 0,46 & 0,51 & 0,51 & 0,48 & 0,48 & 0,48 & 0,58 & 0,65 \\
\hline \multicolumn{2}{|c|}{ Correlation 2000/2011= } & 0,192 & & & & & & & & & & \\
\hline \multicolumn{2}{|c|}{ Correlation 2005/2011= } & 0,018 & & & & & & & & & & \\
\hline
\end{tabular}

Source: BRASIL (2013) and IBGE (2017).

In the 2000-2011 years:

- Correlation malaria infection $x$ cattle herd 2000/2011=0.192

- Correlation malaria infection $x$ cattle herd 2005/2011=0.018

- Average cattle number/population $=1.26$

- Average infection/year (thousands) = 18.9

- Fall of infections cases $(\%)=61.0$

- Growth of cattle herd $(\%)=30.4$

\subsection{Rondônia State (RO)}

Table 11 - (RO) Population, malaria number of infection (10^3), number of cattle herd $\left(10^{\wedge} 6\right)$ and the correlation coefficient Infected people $\times \mathrm{n}$. cattle

\begin{tabular}{|c|c|c|c|c|c|c|c|c|c|c|c|c|}
\hline (RO) & 2000 & 2001 & 2002 & 2003 & 2004 & 2005 & 2006 & 2007 & 2008 & 2009 & 2010 & 2011 \\
\hline pop.(10^3) & 1380 & 1408 & 1432 & 1456 & 1562 & 1535 & 1562 & 1562 & 1562 & 1562 & 1562 & 1562 \\
\hline Infect.(10^3) & 54,07 & 57,68 & 71,22 & 93,85 & 107,12 & 118,64 & 101,65 & 81,93 & 49,81 & 41,37 & 43,58 & 30,41 \\
\hline catt. $\left(10^{\wedge} 6\right)$ & 5,7 & 7 & 8,04 & 9,39 & 10,67 & 11,35 & 11,48 & 11,01 & 11,18 & 11,53 & 11,84 & 12,18 \\
\hline \multicolumn{13}{|c|}{ Correlation $2000 / 2011=\mathbf{0 , 0 5}$} \\
\hline
\end{tabular}

Source: BRASIL (2013) and IBGE (2017).

In the 2000-2011 years:

- Correlation malaria infection $x$ cattle herd 2000/2011=0.05

- Correlation malaria infection $x$ cattle herd 2005/2011=-0.542

- Average cattle number/population $=6.64$

- Average infection/year (thousands) $=70.9$

- Fall of infections cases $(\%)=43.8$

- Growth of cattle herd $(\%)=113.7$ 


\section{DISCUSSION/CONCLUSION}

As stated in the Introduction, the number of entangled environmental variables that determine the dynamic behavior of the system that describes malaria infection is immense, leading to the main variable of the problem: the number of Anopheles bites in humans per unit of time. Changes in this variable imply significant changes in the resulting dynamics for the system. The factor analyzed here is the presence of the cattle herd as a substitute for man as a feeder host.

Tables 3 to 11 show the representativeness of the cattle herd in relation to the size of the population in each state (Average cattle n./pop). The protection level, given by this variable depends on how the herd shares the space of coexistence with the population, but in general, the greater this value, lesser the average number of infected people and vice-versa. A typical example of the former case are the MT and TO states and AM for the last. As explained ahead, the deviations from this trend observed in the focused period are due to epidemic outbreaks, mainly due to deforestation.

In general, the decrease in the number of new infections is accompanied by a growth in the cattle herd in all states of Legal Amazon. The states that present the (negative) correlation between the infection number and the cattle herd in the (2000-2011) years (tables 3 to 11), that reinforce the thesis proposed in this work are: Maranhão (correl. =-0.821); Mato Grosso (correl. $=-0.78$ ); Pará (correl. =-0.72); Tocantins (correl.=-0.69) and Amapá (correl. =-0.234).

The states with positive correlation in the period (2000-2011) are: Acre, Amazonas, Rondonia and Roraima. The reason for this behavior seems to be provoked by the epidemic re-emergence of malaria between 2002 and 2005, mainly in the so-called "Deforestation Arc", namely: $A C, A M$ and $R O$ and throughout $L A$, as shown in table 1 . Recalculating the correlations for these states for the 2005-2006 period results: $A C=-0.395, A M=-0.978, R O=-0.542$ and $R R$ which keeps positive value equal to 0.018. This state (RR) shows a peculiar behavior and new variable on the infection spreading process: Many of the malaria cases are from Venezuelan migrants and indigenous people from the Yanomami tribe (RORAIMA, 2016; JUSBRASIL, 2007; GURGEL; ZANINETTI; FOTSING, 2007).

The analysis of the influence of animals as human substitutes on the dynamics of malaria infection must be extended to all other domestic mammals: Buffalos, equines, mules, donkeys, swine, goat and sheep summarized in the table 12. As can be seen from Tables 12 and Tables 3 to 11, the average number of others animals/population is generally less than the cattle/pop average. However, their influence must be greater than the cattle ones, since their coexistence and proximity of humans, in the day to day is considerably higher than the cattle. It is observed similarly to the cattle case that the state with the highest average of animals/population (MT) has relative lower registered cases of malaria. It also explains why the AP state behavior, where the relative scarcity of cattle $(0.19$ in 2011) is compensated by the greater number of other animals (0.88 in 2011). On the other hand, as with the cattle case in AM state, the scarcity of other animals may be related to a large case of malaria. 
Table 12 - Total of other animals: buffalos, equines, mules, donkeys, swine, goats and sheep in LA

\begin{tabular}{|c|c|c|c|c|c|c|c|c|c|c|}
\hline \multicolumn{2}{|c|}{ animals $\left(10^{\wedge} 6\right)$} & MA & MT & PA & TO & AP & $A C$ & AM & $\mathbf{R R}$ & RO \\
\hline & 2000 & 2,822 & 1,414 & 2,316 & 0,546 & 0,182 & 0,265 & 0,425 & 0,111 & 0,717 \\
\hline & 2011 & 2,364 & 3,077 & 1,933 & 0,672 & 0,6 & 0,322 & 0,283 & 0,095 & 0,602 \\
\hline \multicolumn{2}{|c|}{$\Delta(2011 / 2000)=$} & $-0,16$ & 1,18 & $-0,17$ & 0,23 & 2,30 & 0,22 & $-0,33$ & $-0,14$ & $-0,16$ \\
\hline \multirow{2}{*}{ Anim/Pop } & 2000 & 0,50 & 0,56 & 0,37 & 0,47 & 0,38 & 0,47 & 0,15 & 0,34 & 0,52 \\
\hline & 2011 & 0,35 & 1,00 & 0,25 & 0,48 & 0,88 & 0,43 & 0,08 & 0,20 & 0,39 \\
\hline \multicolumn{2}{|c|}{ Averag(Anim/pop)= } & 0,43 & 0,78 & 0,31 & 0,48 & 0,63 & 0,45 & 0,12 & 0,27 & 0,45 \\
\hline
\end{tabular}

Source: IBGE (2017).

For better statistical validation of the influence of the animals in the development of the disease hypothesis assumed in this work, it is required to make a microscopic analysis, at the level of counties. The data for this level analysis is available in the IBGE (2017) and BRASIL (2017) database.

This work is an investigation of a possible additional cause for the huge decrease in cases of malaria in the states of $\mathrm{LA}$, in addition to the already recognized governmental effort to malaria disease control. The hypothesis adopted is that all domestic animals (exception fowls) compete with the man, as first choice, in the position of hosts feeding of the mosquitoes Anopheles darlingi, the main vector-borne of the disease. In order to prove this hypothesis, it would be necessary to repeat and confirm the studies of intestinal content of engorged mosquitoes done preliminarily by Deane et al. (1949), Oliveira et al. (1989) and Ferreira et al. (1992) in the LA. Similar studies was also carried out in references (BAILLY-CHOUMARA, 1973; BEIER et al., 1988) for the blood meal identification belonging to several mammalian hosts (including human being) for other anopheline species. Only with these laboratory results could one affirm the importance of the hypothesis adopted in this work, respect to other environmental transformations occurred in LA, which would, eventually, act as restricting mechanisms in the dynamics of malaria propagation.

\section{REFERENCES}

ABRAHAM, R.; SHAW, C. Dynamics - The Geometry of Behavior: Part 1. New Jersey: Periodic Behavior, John Wiley \& sons, 2000.

ARAUJO, L. Análise dos focos de calor em áreas florestais ao longo do Arco do Desflorestamento. In: SIMPÓSIO BRASILEIRO DE SENSORIAMENTO REMOTO, 13., Florianópolis, SC, Brasil, 21-26 abril 2007. Anais... São José dos Campos, SP: INPE, 2007. p. 4421-23.

ARON, Joan. Mathematical modeling of immunity to malaria. Mathematical Biosciences, v. 90, p. 385-96, 1988.

BAILLY-CHOUMARA, H. Etude préliminaire d'une recolte d'Anopheles labranchiae par piège CDC réalisée dans la région de Larache, Maroc. Genève: Organisation mondiale de la Santé, 1973.

BARATA, R. Malária no Brasil: panorama epidemiológico na última década. Cadernos de Saúde Pública, Rio de Janeiro, v. 11, n. 1, p. 128-36, jan./mar. 1995.

BEIER, John et al. Bloodmeal Identification by Direct Enzyme-Linked Immunosorbent Assay (ELISA), Tested on Anopheles (Diptera: Culicidae) in Kenya. Journal of Medical Entomology, v. 25, n. 1, p. 9-16, jan. 1988.

BRUMPT, E. A nophélisme sans paludisme et regression spontanée du paludisme. Annales De Parasitologie Humaine Et Comparee, v. 20, n. 1/2, p. 67-91, 1944. 
BULL, C. G.; ROOT, F. M. Preferential feeding experiments with Anopheline Mosquitoes. American Journal of Epidemiology, v. 3, n. 5, p. 514-20, 1923.

CAMUS, D.; TERENCE, H. A Plasmodium falciparum antigen that binds host erythrocytes and merozoites. Science, v. 230, n. 4725, p. 553-6, Nov. 1985.

DEANE, L. et al. Avaliação das preferências alimentares das fêmeas de Anopheles darlingi e Anopheles aquasalis em Belém, Pará, por meio de Provas de precipitina. Revista do Serviço Especial de Saúde Pública, Rio de Janeiro, v. 2, n. 3, p. 793-808, jul. 1949.

DIEKMANN, O.; HEESTERBEEK, J. A. P.; BRITTON, T. Mathematical tools for understanding infection disease dynamics. Princeton: Princeton University Press, 2013.

DOBSON, A.; FOUFOPOULOS, J. Emerging infectious pathogens of wildlife. Philosophical Transactions of the Royal Society of London, v. 356, n. 1411, p. 1001-12, July 2001.

FERREIRA, J. et al. Feeding preference of Anopheles darlingi in malária endemic áreas of Rondonia State - Northwestern Brazil. Memórias do Instituto Oswaldo Cruz, Rio de Janeiro, v. 87, n. 4, p. 601-2, oct./ dec. 1992.

FERREIRA, M.; CASTRO, M. Challenges for malária elimination in Brazil. Malaria Journal, v. 15, n. 1, may 2016. doi: 10.1186/s12936-016-1335-1

GURGEL, H. C.; ZANINETTI, J. M.; FOTSING, J. M. Estudo de casos de malária em Roraima a partir de técnicas de análise espacial. In: SIMPÓSIO BRASILEIRO DE SENSORIAMENTO REMOTO, 13., Florianópolis, SC, Brasil, 21-26 abril 2007. Anais... São José dos Campos, SP: INPE, 2007. p. 2705-12.

INSTITUTO BRASILEIRO DE GEOGRAFIA E ESTATÍSTICA (IBGE). Censo 2010. Available in: <http://www. ibge.gov.br>.

2017. Available in: <http://www.ibge.gov.br>. Access in: 26 July 2017.

INSTITUTO NACIONAL DE PESQUISAS ESPACIAIS (INPE). Prodes - desflorestamento nos municípios da Amazonia Legal, 2008. Available in: <http://www.dpi.inpe.br/prodesdigital/prodesmunicipal.php >. Access in: 1ㅇa․ 2017.

JUSBRASIL. Roraima vive epidemia de malária. 2007. Available in: <http://pr-rr.jusbrasil.com.br/ noticias/2239765/roraima-vive-epidemia-de-malaria>. Access in: 9 aug. 2017.

KAMIMURA, A.; BURANI, G.; FRANÇA, H. The economic system seen as a living system: a Lotka-Volterra framework. Emergence: Complexity \& Organization, v. 13, n. 3, p. 80-93, 2011.

LACROIX, R.; MUKABANA, W.; GOUAGNA, L.; KOELLA, J. Malaria infection increases attractiveness of humans to mosquitoes. PLOS Biology, v. 3, n. 9, 2005. Available in: <https://doi.org/10.1371/journal. pbio.0030298>. Access in: june 2017.

LOIOLA, C. C. P.; SILVA, C. J. M.; TAUIL, P. L. Controle da malária no Brasil: 1995 a 2001. Revista Panamericana de Salud Pública, v. 11, n. 4, p.235-44, Apr. 2002. Available in: <http://dx.doi.org/10.1590/s102049892002000400005>. Access in: 6 july 2017.

MACDONALD, G. et al. Theory of eradication of malaria. Bull. Org. Mond. Santé, v. 15, n. 3-5, p. 369-87, 1956.

MAJORI, G. Short history of malaria and its eradication in italy with short notes on the fight against the infection in the mediterranean basin. Mediterranean Journal of Hematology and Infectious Diseases, v. 4, n. 1, e2012016, 2012. Available in: <https://www.ncbi.nlm.nih.gov/pmc/articles/PMC3340992/>. Access in: 11 july 2017.

BRASIL. Ministério da Saúde, Secretaria de Vigilância em Saúde. Portal da Saúde, 2017. Available in: <http://Brasil.gov.br>. Access in: 15 july 2017.

. Ministério da Saúde, Secretaria de Vigilância em Saúde. Boletim Epidemiológico, Brasília, v. 44, n. 1, 2013. 
BRASIL. Ministério da Saúde do Brasil, Secretaria de Vigilância em Saúde. Boletim Epidemiológico, 2001. Available in: <http://dtr2001.saude.gov.br/svs/pub/pub00.htm\#>. Access in: 13 july 2017.

MIDIAEAMAZONIA. O "arco do desmatamento" na Amazônia. 2014. Available in: <http://midiaeamazonia. andi.org.br/texto-de-apoio/o-arco-do-desmatamento-na-amazonia>. Access in: 28 july 2017.

OLIVEIRA, R. et al. Anopheline species, some of their habits and relation to malária in endemic áreas of Rondonia State, Amazon Region of Brazil. Memórias do Instituto Oswaldo Cruz, Rio de Janeiro, v. 84, n. 4, p. 501-14, oct./dec. 1989.

OLSON, S. H. Desmatamento causa avanço da malária no Brasil. Olson interview to the newspaper $O$ Estado de São Paulo, june 16, 2010.

OLSON, S. H.; GANGNON, R.; SILVEIRA, G. A.; PATZ, J. A. Deforestation and malaria in Mâncio Lima County, Brazil. Emerging Infectious Diseases, v. 16, n. 7, p. 1108-15, july 2010. doi: 10.3201/eid1607.091785

PAHO. Status report on malaria programs in the Americas (based on 2002 data). Washington, D.C.: Pan American Health Organization $-44^{\text {th }}$ Directing Council, 2003. 49p.

RAMSDALE, C. D. The maxillary index. European Mosquito Bulletin, n. 28, p. 32-44, 2010.

RIVERO, S.; ALMEIDA, O.; ÁVILA, S.; OLIVEIRA, W. Pecuária e desmatamento: uma análise das principais causas diretas do desmatamento na Amazônia. Nova Economia, Belo Horizonte, MG, v. 19, n. 1, Jan./Apr. 2009. Available in: <http://dx.doi.org/10.1590/s0103-63512009000100003>. Access in: 21 july 2017.

RORAIMA (State). 3 July 2016. Available in: <http://portal.rr.gov.br/site/?governoderoraima=noticias_ ver\&id=3697>. Access in: 26 july 2017.

ROSS, R. An application of the theory of probabilities to the study of a priori pathometry. Proceedings of the Royal Society, v. 92, n. 638, p. 204-30, feb. 1916.

ROUBAUD, E. Les conditions de nutrition des anófeles em France: Anopheles maculipennis et le rôle du bétail dans le prophylaxie du paludisme. Annales del' Institut Pasteur, n. 34, p. 181-228, 1920.

SAWYER, D. Frontier malaria in the Amazon region of Brazil: types of malaria situation and some implications for control. Brasília, DF: PAHO/WHO, The Special Programme for Research Training in Tropical Diseases, 1988.

SAWYER, D. Malaria on the Amazon frontier: economic and social aspects of transmission and control. The Southeast Asian Journal of Tropical Medicine and Public Health, v. 17, n. 3, p. 342-5, sep. 1986. Available in: <https://www.ncbi.nlm.nih.gov/pubmed/3563600>. Access in: 24 july 2017.

SHONKWILER, R.; ANEKE, S. J. Some mathematical models for malaria. School of Mathematics, Georgia Institute of Technology, Atlanta, GA, 1999. Manuscript. Available in: <http://people.math.gatech. edu/ shenk/Research/Epidemiology/malaria.pdf >. Access in: 19 july 2017.

SILVA, R.; PAIVA, C. H. A. O governo JK e o Grupo de Trabalho de Controle e Erradicação da Malária no Brasil: encontros e desencontros nas agendas brasileira e internacional de saúde, 1958-1961. História, Ciências, Saúde - Manguinhos, Rio de Janeiro, v. 22, n. 1, p. 95-114, 2015. Available in: <https://www. arca.fiocruz.br/handle/icict/14446>. Access in: 15 july 2017.

SMITH, D.; MCKENZIE, F. E.; SNOW, R. W.; HAY, S. I. Revisiting the basic reproductive number for malaria and its implications for malaria control. PLOS Biology, 2007. Available in: <https://doi.org/10.1371/journal. pbio.0050042.t002.. Access in: 14 july 2017.

SWELLENGREBEL, N. H. The malaria epidemie of 1943-1946 in the Province of North-Holland. Transactions of the Royal Society of Tropical Medicine and Hygiene, v. 43, n. 5, p. 445-61, 1950.

TOTY, C. et al. Malaria risk in Corsica, former hot spot of malária in France. Malaria Journal, v. 9, 231, 2010.

VITTOR, A. Y. et al. The effect of deforestation on the human-biting rate of Anopheles darlingi, the primary vector of falciparum malaria in the Peruvian Amazon. The American Journal of Tropical Medicine and Hygiene, v. 74, n. 1, p. 3-11, jan. 2006. 
WAITE, H. Mosquitoes and malaria. A study of the relation between the number of mosquitoes in a locality and the malaria rate. Biometrika, v. 7, n. 4, p. 421-36, nov. 1910.

WORLD HEALTH ORGANIZATION (WHO). Malaria. 2017. Available in: <http://www.who.int/malaria/en/>. Access in: 15july 2017.

\section{About the authors:}

Arlindo Kamimura: PhD in Energy Planning from UNICAMP. Consultant / Collaborator at IEE / USP. E-mail: kamimura@iee.usp.br

Geraldo Burani: PhD in Electrical Engineering from the University of São Paulo, Brazil. Professor and Vice Mayor of the USP Campus of the Capital of the University of São Paulo. E-mail: burani@iee.usp.br

Ildo Sauer: PhD in Nuclear Engineering from the Massachusetts Institute of Technology, USA. Full Professor at the University of São Paulo. E-mail: ilsauer@iee.usp.br

\section{Acknowledgements}

The authors would like to thank Dr. Eduardo de Azeredo for pointing out the pioneering work on the feeding habits of Anopheles darling in the Legal Amazonia. Thanks to Dr. Alessandro Barghini and Dr. Donald Sawyer for the helpful comments and the Institute of Energy and Environment of University of Sao Paulo for their support in the development of this work. Thanks also to the anonymous referee for the comments and useful suggestions. 